\title{
Hydrologic responses of shortgrass prairie ecosystems
}

\author{
LAURA WELTZ , GARY FRASIER, AND MARK WELTZ
}

Authors are former research assistant, Colorado State University, Fort Collins, Colo. 805236; Research Hydraulic Engineer, USDA-ARS, Rangeland Resources Research, 1701 Center Ave. Fort Collins, Colo. 80526; and Rangeland Scientist, USDA-ARS, Great Plains Systems Research, Fort Collins, Colo. 80522 .

Abstract

Runoff hydrographs from 3 separate rainfall simulation runs at 11 different shortgrass prairie sites were evaluated to determine the hydrologic similarity within a single ecosystem at widely separated sites. There were no consistent patterns in the equilibrium runoff among sites and simulator runs. When the sites were stratified by soil type, there were differences in time-topeak of the runoff event and the regression slope of the rising limb of the runoff ratios. Spearman's rank correlation showed no relation of the rising limb slope regression coefficient to measured vegetative characteristics across all sites. There was minimal correlation between the runoff regression coefficient and the percent cover and bare soil. Differences in the biotic components of the sites were not useful in predicting runoff characteristics. If equilibrium runoff was the measured hydrologic response, the sites were dissimilar. Using the time-to-peak and slope of the rising limb components of the runoff hydrograph, the sites were similar on the same soil type. The technique of comparing components of the runoff hydrograph, other than equilibrium runoff has promise to allow one to quickly compare responses among ecosystems to determine if they have similar hydrological functions. Our study on shortgrass prairie sites indicated that easily estimated factors such as biomass, cover and litter were not good indicators of hydrologic function. Also, it is necessary to identify which portion of the runoff event is most important in the assessment. Future hydrologic and erosion models need to develop nonlinear prediction equations to estimate infiltration rates as a function of cover, biomass, and soil properties and also to stratify soils into functional units to accurately estimate runoff rates.

Key Words: Runoff, rainfall simulation, hydrograph, time-topeak

Rangelands and permanent pasture comprise approximately $51 \%$ of the world's land surface with grazinglands covering 364 million hectares in the 17 western states of the United States (Child and Frasier 1992). Rangeland ecosystems are complex and many of the interacting abiotic and biotic processes are not clearly defined with regards to their resistance and resilience to stress, making the assessment of health or stability of a rangeland ecosystem extremely difficult. Recent efforts have been devoted to developing techniques to assess the stability and health of rangeland ecosystems (NRC 1994, USDA-NRCS 1997). The USDA-Natural Resources Conservation Service (NRCS) proposed that rangeland health be evaluated using 17 indicators to

Manuscript accepted 21 Oct. 1999.

\section{Resumen}

Se evaluaron hidrográficas de escurrimiento de 3 eventos de simulación de lluvia independientes conducidos en 11 sitios diferentes de pastizal corto, esto con el objetivo de determinar la similitud hidrológica de sitios ampliamente separados dentro de un solo ecosistema. Entre sitios y eventos de simulación de lluvia no hubo patrones consistentes en el equilibrio de escurrimiento Cuando los sitios se estratificaron por tipo de suelo, si hubo diferencias en el tiempo de máximo escurrimiento y la pendiente de la parte de la curva de regresión que representa el mayor aumento de los porcentajes de escurrimiento. Las pruebas de correlación del rango de Spearman no mostraron relación entre el coeficiente de la pendiente de la parte de la curva de regresión que representa el mayor aumento de los porcentajes de escurrimiento y las características de vegetación medidas a través de los sitios. Hubo una correlación mínima entre el coeficiente de regresión del escurrimiento y el porcentaje de cobertura y de suelo desnudo. Las diferencias de los componentes bióticos de los sitios no fueron útiles para predecir las características del escurrimiento. Si el equilibrio del escurrimiento fue la respuesta hidrológica medida, los sitios fueron disímiles. Utilizando el tiempo de máximo escurrimiento y la pendiente de la parte de las hidrográficas de que representan el mayor aumento de los porcentajes de escurrimiento los sitios fueron similares en el mismo tipo de suelo. La técnica de comparar los componentes de la hidrográfica de escurrimiento en lugar del equilibro de escurrimiento promete permitirle a uno comparar rápidamente las respuestas entre ecosistemas para determinar si ellos tienen funciones hidrológicas similares. Nuestro estudio en sitios de pastizal corto indico que factores fácilmente estimados como la biomasa, cobertura y mantillo no fueron buenos indicadores de la función hidrológica. También, es necesario identificar cual porción del evento de escurrimiento es más importante para esta evaluación. Los futuros modelos de escurrimiento y erosión necesitan desarrollar ecuaciones de predicción no lineales para estimar las tasas de infiltración como una función de la cobertura, biomasa y propiedades del suelo y también estratificar los suelos en unidades funcionales para estimar con exactitud las tasas de escurrimiento.

describe 3 attributes (soil site stability, watershed and hydrologic cycle, and soil and plant community integrity) of a functioning ecosystem. Each of these indicators is ranked within 1 of 5 categories. The categories range from the most degraded state to the condition expected for the site based upon the site ecological site description. Many of the indicators are used in more than 1 of the 3 attributes of a healthy ecosystem. Five of the 17 rangeland health indicators are directly associated with the hydrologic com- 
ponents of a site. The NRCS procedure is qualitative and poses difficulty for someone not familiar with the site where specific baseline data is not available for comparison. The reliance on expert opinion to define "preponderance of evidence" as the methodology to define the health of the 3 components and no method to define the health of the entire site may result in distrust of the system and failure to adopt the approach as a method to estimate the health or stability of the site. Within the past decade, a number of studies using similar equipment and techniques have been conducted to evaluate infiltration, runoff and soil erosion across the broad spectrum of rangelands in the western part of the United States (Simanton et al. 1991). While the primary purpose of the many studies was to provide data for the Water Erosion Prediction Project (WEPP) (Flanagan and Livingston 1995), the data sets provide a unique opportunity to provide information on the hydrologic similarity of a single ecosystem type across a large geographical area and to develop a quantitative method to define hydrologic function that could be incorporated into any rangeland health evaluation technique.

Our study utilizes data sets collected from selected rainfall simulation studies to evaluate the surface runoff response of 11 different shortgrass prairie sites as affected by canopy cover, ground cover, standing biomass, litter, and soil texture. Data sets used in the analysis were collected on semiarid shortgrass prairies located in; Colorado, New Mexico, South Dakota, and Texas (Weltz 1995).

Many factors influence the shape of the runoff hydrograph curve, but the most important variables are rainfall characteristics, soil properties, vegetation, and land use (Dunne and Leopold 1978). In our study, variability was reduced by restricting the analysis to shortgrass ecosystems and controlled rainfall simulated events. Our hypothesis was that ecosystems with similar dominant plant species composition and soil textures should have similar hydrological runoff responses.

Because runoff is time dependent and varies continuously, it is difficult to derive a single index for statistical comparisons across different experimental sites and rainfall events. The most common method used to evaluate differences between sites have been to compare either total runoff or final infiltration rates (Blackburn 1975, Weltz and Wood 1986, Wood 1987). Other researchers have utilized time to peak, runoff rate, or total runoff volume to compare hydrographs (Stone et al.1992,
Tiscareno-Lopez et al. 1993). Weltz et al. (1992) used an optimization technique to fit the rising limb of the hydrograph to determine the hydrologic roughness of rangelands. Spaeth et al. (1996) used indirect gradient analysis to define relationships between plant communities, soil variables, and infiltration rates.

Our study utilized the concept of subdividing the hydrograph into separate components for analysis to see if any or all of the hydrograph components are similar or dissimilar among sites (Frasier et al. 1998a). This allows an evaluation of the entire hydrograph shape between sites and within sites in relation to site characteristics.

\section{Methods and Materials}

\section{Study Sites:}

Study sites were all located within shortgrass plant communities (Table 1). One data set was originally collected for the Water Erosion Prediction Project (WEPP) research studies by the USDA-National Resource Soil Conservation Service (NRCS) and USDA-Agricultural Research Service (ARS) Interagency Rangeland Water Erosion Team project (IRWET). The second set was collected for the USDA-ARS Water Erosion Prediction Project database (unpublished data). The third data set was collected at the ARSCentral Plains Experimental Range, Nunn, Colorado (CPER) (Frasier et al.1995).

Range site classification of the study sites varied from sandy plains to clayey with range condition from poor to excellent. Slopes of the study plots were mostly in the range of 5 to $8 \%$ and soil textures varied from sandy loam to clay. The predominant plant species were Bouteloua gracilis (H.B.K.) Lag. and Buchloe dacty loides (Nutt.) Engelman. Average annual precipitation ranged from 250 to $400 \mathrm{~mm}$ $\mathrm{yr}^{-1}$ (Table 1). The site in South Dakota (H2) was classified as a mixed prairie potential plant community but the site had been historically heavily grazed causing the plant community to shift to a shortgrass plant community (Hanson et al. 1978).

\section{Rainfall Simulation:}

Runoff experiments for all sites used large rotating boom rainfall simulators similar to the one developed by Swanson (1965). All studies used the same general procedures with a few minor differences. Plot size varied from 3.0 to $3.5 \mathrm{~m}$ wide and 10.0 to $10.7 \mathrm{~m}$ long. All plots had sheet steel metal borders driven into the soil around the upper and side edges.
Troughs at the lower edge of each plot collected and directed the runoff water through small critical depth flumes. With the exception of the Texas sites (Table 1), depth of water flowing through the flumes was measured and recorded with bubble flow meters at 1 minute intervals. The flow depths were converted to equivalent runoff rates. At the Texas sites, runoff rates were measured volumetrically at 2 min intervals.

While the various rainfall simulation studies were conducted by different investigators with slightly different procedures, it was possible to select data sets with the same general antecedent soil moisture conditions and the same basic water application quantity and pattern (rainfall simulation). The rainfall simulation pattern selected for this evaluation consisted of 3 separate water application periods. 1) Dry run-simulated rainfall applied at a nominal rate of 50 to $60 \mathrm{~mm} \mathrm{hr}^{-1}$ onto soils with existing soil moisture (no prewetting). Simulation duration was sufficient to reach equilibrium runoff, usually within 45 to $60 \mathrm{~min}$. 2) Wet run-following a 30 min interval of no water application after the dry run (or an equivalent pre-conditioning water application) simulated rainfall was applied at nominal rate of 50 to 60 $\mathrm{mm} \mathrm{hr}{ }^{-1}$ until runoff reached equilibrium, usually within about $30 \mathrm{~min}$. 3) Very wet run-without stopping the rainfall simulation at the end of the wet run, the water application rate was increased to 100 to $130 \mathrm{~mm} \mathrm{hr}^{-1}$ until runoff equilibrium was achieved, usually within about $20 \mathrm{~min}$.

While the rainfall simulators were all the same design, it should be noted that for each application phase, simulator application rates were slightly different because of changes in water level in the water storage tanks, blowing wind, and different pressures on the simulator nozzles. This caused some variation in application rates. Actual water application rates and quantities were measured on each plot during the simulation events.

\section{Vegetation Measurement:}

The Interagency Rangeland Team (IRWET) estimated standing biomass using the NRCS double sampling procedure (USDA-SCS 1976). Five sample quadrats were collected on each runoff plot. The sample sites were horizontally centered within the plot at intervals of 1 , $3,5,7$, and $9 \mathrm{~m}$ from the bottom of the plot. The quadrats were clipped to a height of $1 \mathrm{~cm}$ above the ground surface. Standing biomass was separated by species into 3 categories: 1) previous 
Table 1. Site location, range site, range condition, number of years sampled, number of samples per year, soil texture, percent slope, and dominant plant species (percent composition by weight) for rainfall simulation study areas.

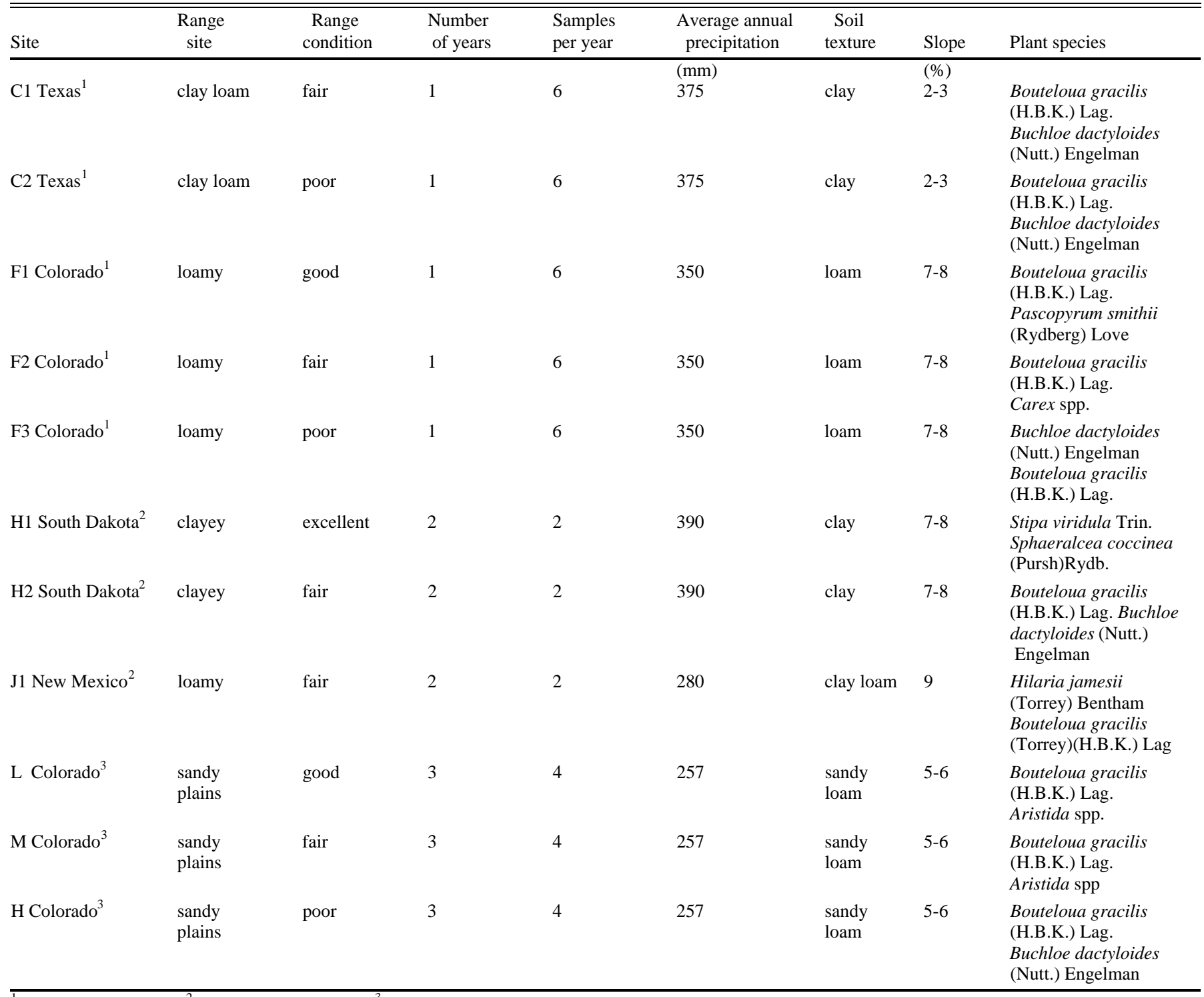

${ }^{1}$ Data supplied by NRCS, ${ }^{2}$ data supplied USDA-ARS, ${ }^{3}$ data from CPER.

year's growth, 2) current year growth, and 3) standing litter. Detached litter within the quadrat was also collected. All biomass samples were dried at $60^{\circ} \mathrm{C}$ for 72 hours and weighed.

For the USDA-ARS Water Erosion Prediction Project (WEPP) standing biomass was estimated by clipping six, $0.5 \mathrm{~m}$ by $1 \mathrm{~m}$ quadrats located outside of the large rainfall simulation plots. Quadrats were clipped to $1 \mathrm{~cm}$ of the soil surface by life form (grass, forb, shrubs, and cacti). The quadrats were located $1 \mathrm{~m}$ from the runoff plots and placed $1 \mathrm{~m}$ from the top and the bottom of the plot and at the midpoint of the plot. Once the standing biomass was removed from the quadrats, all litter was removed. All biomass samples were dried at $60^{\circ} \mathrm{C}$ for 72 hours and weighed.

In the CPER study, aboveground biomass was estimated with a double-sample procedure on 10 randomly located quadrats $(0.31$ by $0.31 \mathrm{~m})$. Every fifth quadrat was clipped by species, dried at $60^{\circ} \mathrm{C}$ for 72 hours and weighed. Litter weights were not recorded.

Canopy cover was defined as the soil surface area protected from raindrop impact by standing plant material looking straight down into the canopy (0-100\%). Ground cover was defined as the amount of litter, cryptogams, plant basal area, and impervious material that protects the soil surface from raindrop impact (0-100\%). For this study we combined canopy and ground cover and represented it as total cover (0-200\%).

For the Interagency Rangeland Team (IRWET) and ARS studies, canopy and ground cover was estimated with a 49-pin point-sampling frame. The frame was placed at 10 even intervals $(1 \mathrm{~m})$ on each plot, starting at $0.5 \mathrm{~m}$ from the outlet of the plot. Canopy cover was recorded by life form and ground cover by class (soil, rock, litter, basal, and cryptogams). In the CPER study, basal cover was measured using a 10 point frame. Four transects were established down the length of the plot at equal intervals from the plot sidewalls. The point 
frame was set perpendicular to the transect and basal cover was estimated at $3 \mathrm{~m}$ intervals on each transect.

\section{Data Analysis:}

It should be noted that sites within this study should not be considered as replications. Because of small differences in water application rates from the various rotating boom rainfall simulators, the runoff rate was adjusted (normalized) by the water application rate (rain) for each recorded time interval and each simulation period (Frasier et al. 1998a).

The normalized runoff (percent runoff) hydrograph for each simulation period is separated in 3 sections, time to runoff initiation, the rising limb, and equilibrium runoff. The end points of the segments (rising limb and equilibrium runoff phases) are determined using the break-point approach originally developed for analyzing precipitation data (Brakensiek et al. 1979). This approach uses an iterative least squares regression analysis and maximizes the coefficient of determination for the segment being evaluated. If the time to initiation of runoff, time to runoff equilibrium, regression slope of the rising limb, and final equilibrium runoff rate are statistically similar, then there is no difference in the treatment response. Differences in 1 or more characteristics may indicate different hydrologic responses to the variables or treatments (Frasier et al. 1998a).

Descriptive statistics (mean, SE, median, mode, SD, and range) were used to compare the time to runoff peak, regression slope of the rising limb, and the steady state portions of the hydrographs. ANOVA was used to find significant differences $(P<0.05)$ in vegetation characteristics (biomass, litter, and cover) among sites and within the sites. Correlation analysis among and between sites evaluat-

Table. 2. Total cover, mean standing biomass and total litter at rainfall simulation sites.

\begin{tabular}{lccc}
\hline \hline Site & $\begin{array}{r}\text { Total Cover } \\
(\% \pm \mathrm{SD})\end{array}$ & $\begin{array}{c}\text { Mean Standing Biomass } \\
\left(\mathrm{Kg} \mathrm{ha}^{-1} \pm \mathrm{SD}\right)\end{array}$ & $\begin{array}{c}\text { Total Litter } \\
\left(\mathrm{Kg} \mathrm{ha}^{-1} \pm \mathrm{SD}\right)\end{array}$ \\
\hline C1 Texas & $94 \pm 9.2$ & $1974 \pm 881$ & $1778 \pm 1235$ \\
C2 Texas & $93 \pm 9.9$ & $651 \pm 234$ & $1511 \pm 583$ \\
F1 Colo & $129 \pm 2.9$ & $1005 \pm 277$ & $1893 \pm 1354$ \\
F2 Colo & $105 \pm 17.7$ & $746 \pm 255$ & $1567 \pm 705$ \\
F3 Colo & $102 \pm 3.4$ & $380 \pm 141$ & $685 \pm 241$ \\
H1 SD & $84 \pm 11.6$ & $1600 \pm 274$ & $753 \pm 125$ \\
H2 SD & $92 \pm 18.6$ & $450 \pm 141$ & $247 \pm 99$ \\
J1 NM & $52-$ & $649 \pm 90$ & $164 \pm 28$ \\
L Colo & $82 \pm 1.3$ & $519 \pm 35$ & - \\
M Colo & $79 \pm 2.3$ & $490 \pm 68$ & - \\
H Colo & $76 \pm 3.4$ & $412 \pm 14$ & - \\
\hline
\end{tabular}

ed effects of vegetation characteristics on the hydrologic responses.

\section{Results and Discussion}

Vegetation-The mean percentage for total cover (canopy plus ground) over all sites was $86 \%$ with a standard deviation of 17 . The mean total aboveground biomass for all the sites was $725 \mathrm{~kg} \mathrm{ha}^{-1}$ with a maximum of $1974 \mathrm{~kg} / \mathrm{ha}$ at the Texas $\mathrm{C} 1$ site and a minimum of $380 \mathrm{~kg} \mathrm{ha}^{-1}$ at the Colorado site F3 (Table 2). The mean litter over all sites (except CPER sites where litter was not estimated) was $533 \mathrm{~kg} \mathrm{ha}^{-1}$ with a maximum of $1893 \mathrm{~kg} \mathrm{ha}^{-1}$ at the Colorado site F1 and the minimum of $247 \mathrm{~kg}$ $\mathrm{ha}^{-1}$ at the South Dakota site $\mathrm{H} 2$.

Runoff Time-toPeak-As the soil texture became finer (sandy loam

$\rightarrow$ clay) the time-to-peak of the runoff event during the dry run became progressively greater ranging from 20 to $30 \mathrm{~min}$ on the sandy loam and loam soil to nearly 40 minutes on the clay soil (left side, Fig. $1)$. This is contrary to common concepts where the infiltration rate increases (runoff decreases) as soil texture becomes coarser. A possible explanation is that the clay soil textured sites develop cracks, which, when dry absorb considerable water until they swell shut. Another explanation is that a vegetation characteristic such as litter may be having a possible influence on the infiltration rate of the clay site. The differences among soil types became less as the soil became wet (wet run) (center groups, Fig. 1) and with increased water application rate (very wet run) (right side, Fig. 1).

Runoff Rising Limb Slope-The regression slope of the rising limb of the runoff ratios during the initial phase (dry run) of the runoff events were similar, with regression coefficient slope values varying from 2 to 4 across all sites (left side, Fig. 2 ). In the wet runs the slope regression coefficients remained unchanged on the sandy loam soil (2 to 4 ) but increased to 4 to 8 on the loam and clay sites (center groups, Fig. 2). In the very wet runs the slope regression coefficients were 6 to 12 for the clay sites, 6 to 8 for the loam sites and 2 to 4 for the sandy loam sites (right side, Fig. 2).

As the regression slope of the runoff hydrograph rising limb increased, so did the variability among plots especially in the wet and very wet runs on the clay and loam soil sites, (standard deviation bars, Fig. 2). The variability among runs (large standard deviations) with the higher rainfall intensities (very wet runs) indicated that there were additional factors affecting 
Oag Son
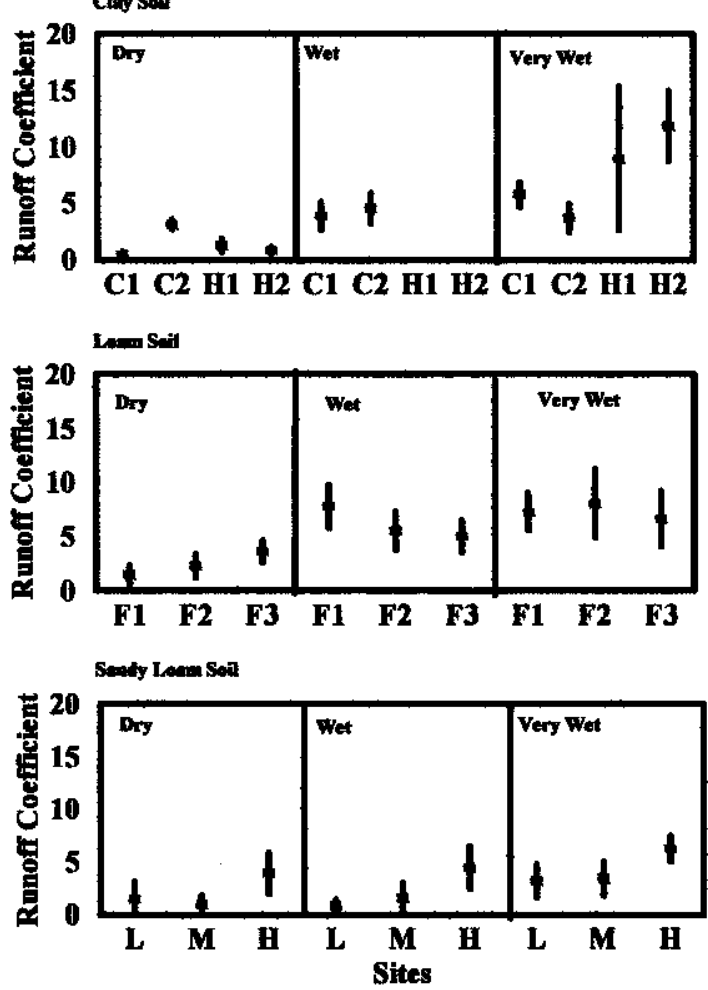

Fig. 2. Mean and standard deviations of the regression coefficient of the slope of rising limb of hydrographs for dry, wet, and very wet rainfall simulation runs on shortgrass prairie sites (stratified by soil texture).
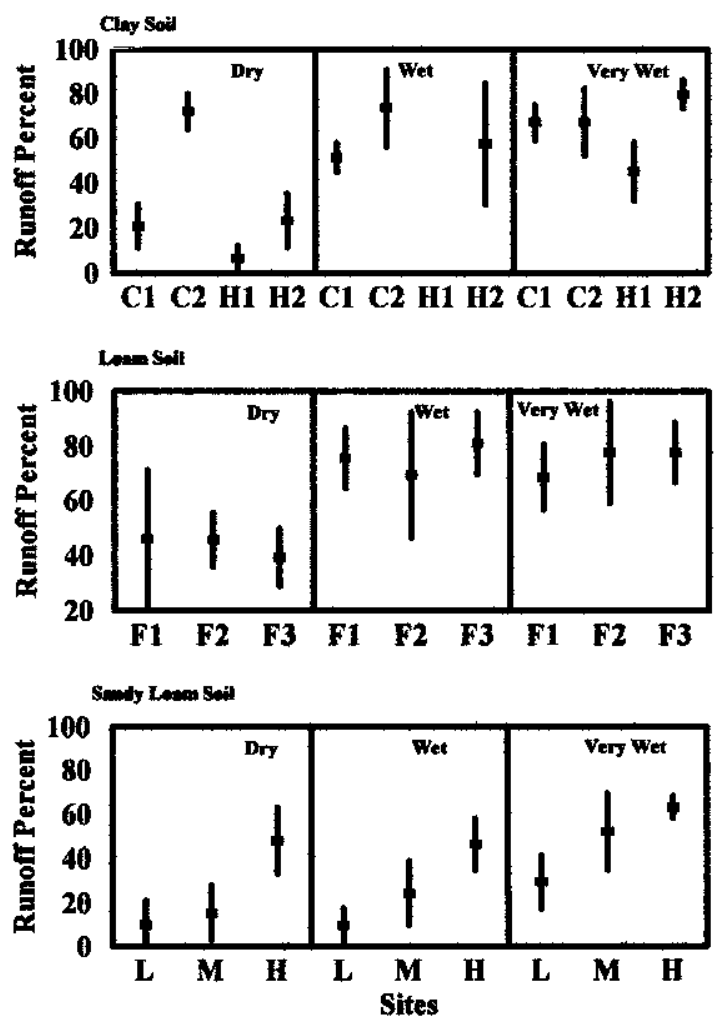

Fig. 3. Mean and standard deviations of the equilibrium runoff percentage for dry, wet, and very wet rainfall simulation runs on shortgrass prairie sites (stratified by soil texture). the runoff and/or infiltration rates not apparent during the dry runs. There has been some speculation that in high intensity rainstorms the impact of raindrops can separate soil aggregates on the surface and ultimately wash these particles into the soil pores, reducing the infiltration rate. Therefore, in such storms it is the final rate of infiltration that primarily determines how much total runoff is generated (Dunne and Leopold 1978). Dunne et al. (1991) proposed that as rainfall intensity increases there will be a non-linear change in infiltration rate. They speculated that the reason for this increase could be the interaction of flow depth (head) with the hydraulic conductivity of the mineral soil, the influence of microtopographic features on routing of water, and that the impact of hillslope gradient and length becomes greater with increased flow velocities.

For most clay and loam sites, as the rainfall rate increased there was an increase in the regression coefficient of the runoff hydrograph rising limb. In contrast, the sandy loam sites at CPER did not show a consistent pattern of increased runoff at the higher rainfall events. Varying the intensity of the rainstorm event $\left(50 \mathrm{~mm} \mathrm{hr}^{-1}\right.$ to 100 $\mathrm{mm} \mathrm{hr}^{-1}$ ) had little effect on the slope of the runoff hydrograph rising limb. The hypothesized reason that the sandy loam site did not respond in the same manner as the loam and clay soils is that the rainfall intensity was not sufficient to overcome the high infiltration rates of the non-contributing portions (basal area of plants) of the sandy loam plots.

The relationship between the regression coefficient of the slope of the runoff hydrograph rising limb for the dry, wet, and very wet runs and biotic characteristics was evaluated using a correlation matrix (SAS 1988). Spearman rank correlation $\left(r_{s}\right)$ values show no consistent correlation between the regression coefficient of the slope of the runoff hydrograph rising limb and measured vegetative characteristics across all sites. There was no cor-

relation between the runoff regression coefficient and the percent cover and bare soil (Table 3).

There was a moderate negative correlation $\left(\mathrm{r}_{\mathrm{s}}\right)$ with the regression coefficient of the slope of the runoff hydrograph in the dry run indicating slower runoff on sites with more vegetation. There was no correlation of biomass to the regression coefficient for the wet and very wet rainfall simulation events. This indicated that biomass was more important in reducing surface runoff for dry soils than it was for wet soils. One possible explanation is that during the initial rainfall sequence, runoff was slowed down (increased hydraulic resistance to water flow by the standing vegetation) allowing the water to infiltrate into the soil. During the wet and very wet runs

Table 3. Spearmans coefficient of rank correlation $\left(r_{s}\right)$ of the slope of the rising limb of runoff hydrograph for dry, wet, and very wet rainfall simulation events and biotic characteristics across all shortgrass prairie sites.

\begin{tabular}{lccccc}
\hline \hline Runoff event & $\begin{array}{c}\text { Number } \\
\text { observations }\end{array}$ & $\begin{array}{c}\text { Cover } \\
(\%)\end{array}$ & $\begin{array}{c}\text { Bare soil } \\
(\%)\end{array}$ & $\begin{array}{c}\text { Biomass } \\
(\mathrm{kg} / \mathrm{ha})\end{array}$ & $\begin{array}{c}\text { Litter } \\
(\mathrm{kg} / \mathrm{ha})\end{array}$ \\
\hline Dry & 19 & 0.12 & -0.18 & -0.47 & -0.04 \\
Wet & 14 & 0.27 & -0.12 & -0.02 & 0.62 \\
Very wet & 19 & 0.25 & 0.09 & 0.05 & 0.42 \\
\hline
\end{tabular}


Table 4. Coefficient of determination $\left(\mathrm{r}^{2}\right)$ of slope regression coefficient of rising limb of the runoff hydrograph for the dry, wet, and very wet rainfall simulation events and biotic characteristics stratified by soil texture for all shortgrass prairie sites.

\begin{tabular}{llccc}
\hline \hline & & \multicolumn{3}{c}{ Rainfall sequence } \\
\cline { 3 - 5 } Soil texture & Vegetation & Dry & Wet & Very wet \\
\hline Clay & Biomass (kg/ha) & 0.10 & $\mathrm{M}$ & 0.15 \\
Clay & Cover (\%) & 0.01 & $\mathrm{M}$ & 0.28 \\
Clay & Litter (\%) & 0.20 & $\mathrm{M}$ & 0.40 \\
Loam & Biomass (kg/ha) & 1.00 & 0.82 & 0.28 \\
Loam & Cover (\%) & 0.73 & 0.99 & $<0.01$ \\
Loam & Litter (\%) & 0.98 & 0.68 & 0.42 \\
Sandy loam & Biomass (kg/ha) & 0.58 & 0.58 & 0.18 \\
Sandy loam & Cover $(\%)$ & 0.18 & 0.78 & 0.18 \\
Sandy loam & Litter (\%) & $\mathrm{M}$ & $\mathrm{M}$ & $\mathrm{M}$ \\
\hline
\end{tabular}

$\mathrm{M}$ is data missing or not available.

the infiltration rate may have decreased sufficiently to reduce the impact of increased hydraulic resistance associated with increased biomass. At sufficiently high water application rates the runoff rate may be minimally affected by biomass.

Litter was not correlated with the runoff rising limb regression coefficient in the dry run, but was highly correlated in the wet run and to a lesser degree in the very wet run (Table 3 ). These results conflict with other reports showing that runoff rate deceases as litter increases, (Simanton et al. 1991, Blackburn et al. 1992, Thurow et al. 1986, and Packer 1951). The difference in apparent results from other studies is attributed to the portion of the runoff hydrograph used in the analysis. Our studies used the rising limb portion while many other studies use equilibrium runoff values. This illustrates the need to insure that the portion of the runoff event be clearly identified and also representative of the factors being investigated. While the exact cause for the difference between the dry and wet or very wet runs can not be determined, we speculate that there is a transient hydrophobic response in shortgrass plant communities similar to that for burned chaparral sites in California (Debano 1975 ). During the initial rainfall event the soluble organic compounds on the litter significantly affect the infiltration rate independently of the quantity of litter on the soil surface. This effect can become more pronounced as the litter quantity increases. After the litter has been wetted for a period of time (wet run) the influence of the water repellency is reduced (Frasier et al. 1998b). This litter effect is minimized somewhat during the very wet run because of the high volume of water. In addition, the slight increase in head pressure caused by the increased depth of overland flow can help offset the hydrophobic conditions in the soil profile. More research will be needed to determine if and under what circumstances hydrophobic layers exist in short grass prairies, as litter builds up due to changes in management practices or climate.

Soil type modified the impact of biotic characteristics (biomass, cover, and litter) on the regression coefficient of the slope of the rising limb of the runoff hydrograph (Table 4). For the clay soils, standing biomass, litter, and cover had little correlation with the regression coefficient of the rising limb especially in the dry run. As rainfall intensity and soil moisture increased (very wet run), there were higher correlations of the biotic components with the rising limb runoff regression coefficient.

On the loam soils there were significant biotic effects on the slope of the rising limb runoff regression coefficient in both the dry and wet runs. As rainfall intensity and soil moisture increased (very wet run), these influences decreased (Table 4). The influence of cover was more important during the wet run, as opposed to the dry runs where biomass and litter were more correlated with the rising limb of the runoff hydrograph. Cover was not related to the runoff coefficient of the rising limb for the very wet runs.

For the sandy loam soils the biomass had a moderate effect on the rising limb runoff regression coefficient in the dry and wet runs but no effect in the very wet run. Cover had an effect on only the wet run. Litter was not measured on the sandy loam soils.

Equilibrium Runoff-The equilibrium runoff ratios (runoff rate divided by rainfall intensity) did not consistently vary among sites and simulator runs (ie., dry run vs. wet run ) (Fig. 3). Mean equilibrium runoff rates on the clay soils ranged from 10 to $75 \%$ in the dry run, 55 to $60 \%$ in the wet run and 40 to $80 \%$ in the very wet run. On the loam soil sites the mean equilibrium runoff was 40 to $45 \%$ in the dry run and 70 to $80 \%$ for the wet and very wet runs. On the sandy loam sites at CPER (Colo L, M, H) mean equilibrium runoff ranged from 10 to $50 \%$ on the dry and wet runs and was 30 to $60 \%$ on the very wet runs. Frasier et al. (1995) had found on these sites an increase in equilibrium runoff rates with higher grazing intensity (Fig. 3). Some of the CPER sites never reached an equilibrium runoff rate during the time allowed for their dry, wet and very wet runs because the applied rainfall rate did not exceed the saturated hydraulic conductivity of the soil. Plots where equilibrium runoff was not achieved were not used in calculating the mean and standard deviations.

\section{Summary and Conclusions}

We evaluated the hypothesis that shortgrass prairie ecosystems with similar vegetation and cover would have similar hydrological runoff responses. Runoff hydrographs from 3 separate rainfall simulation runs (dry, wet, very wet) at 11 different shortgrass prairie sites were evaluated to determine the hydrologic similarity within a single ecosystem type at widely separated sites. To obtain a clearer understanding of the interaction of the biotic and abiotic factors affecting runoff, the runoff hydrographs were separated into time-to-peak, slope of the rising limb, and steady state runoff components. To evaluate the effect of site biotic components, the regression slope of the rising limb of the runoff hydrograph was correlated to selected biotic factors.

When the sites were stratified by soil type differences, some runoff characteristics were detected. As the soil texture became finer, the time-to-peak of the runoff event during the dry run became progressively greater. The differences in time-to-peak among soil types became less as the soil became saturated (wet run) and with increased water application rate (very wet run). The regression coefficients of the slope of the runoff hydrograph rising limb during the initial phase (dry run) were similar across all sites. In the wet runs the mean runoff regression slope coefficients remained unchanged on the sandy loam soil but doubled on the loam and clay sites. In the very wet runs the mean runoff regression slope coefficients continued to increase for the clay sites but were unchanged on the loam and sandy 
loam sites. Spearman rank correlation coefficient $\left(r_{s}\right)$ values show no consistent correlation pattern of the slope of the runoff hydrograph rising limb regression equation to measured vegetative characteristics across all sites. There was no consistent correlation between the runoff regression coefficient and the percent cover and bare soil. Equilibrium runoff (runoff rate divided by rainfall intensity) was not a good comparative parameter among sites and simulator runs.

The data analysis showed that biotic components (biomass, cover, litter) across all the sites were not useful in predicting hydrologic differences as measured by the slope of the rising limb of the runoff hydrograph. When stratified by soil type, biomass, cover and litter were significantly correlated to the slope of the rising limb, of the runoff hydrograph.

Were the 11 shortgrass prairie sites used in the evaluation hydrologically different? If equilibrium runoff was the measured hydrologic response, the sites were dissimilar. When using the time-topeak and the regression coefficient of the slope of the runoff hydrograph rising limb the sites on the same soil type were hydrologically similar.

Can we assess the hydrologic components of rangeland health or sustainability by visual assessment of a site? Our study on shortgrass prairie sites indicated that easily estimated factors such as biomass, cover and litter were not good indicators of hydrologic function. Also, it is necessary to identify which portion of the runoff event is most important in the assessment. Future hydrologic and erosion models need to develop nonlinear prediction equations to estimate infiltration rates as a function of cover, biomass, and soil properties and also to stratify soils into functional units to accurately estimate runoff rates.

\section{Literature Cited}

Blackburn, W.H. 1975. Factors influencing infiltration and sediment production of semiarid rangelands in Nevada. Water Resour. Res. 11(6):929-937.

Blackburn, W.H., F.B. Pierson, C.L. Hanson, T.L. Thurow, and A.L. Hanson. 1992. The spatial and temporal influence of vegetation on surface soil factors in semiarid rangelands. Trans. ASAE. 35 (2):479-486.

Brakensiek, D.L., H.B. Osborn, and W.J. Rawls 1979. Field manual for research in agricultural hydrology. USDA-SEA Agr. Handb. No. 224. 558 pgs.

Child, R.D. and G.W. Frasier 1992. ARS range research. Rangelands 14:17-32.
DeBano, L.F. 1975. Infiltration, evaporation and water movement as related to water repellency. In: Soil Conditioners. Ed B.A. Stewart. SSSA Special Publ. Series No. 7, Soil Sci. Soc. Amer. pgs 155-164.

Dunne, T. and L.B. Leopold. 1978. Water in environment planning. W.H. Freeman and Company, New York.

Dunne, T., Z. Weihua, and F.A. Brain. 1991. Effects of rainfall, vegetation, and microtopography on infiltration and runoff. Water Resour. Res. 29 (9):2271- 2284.

Hanson, C.L., A.R. Kuhlman, and J.K. Lewis. 1978. Effect of grazing intensity and range condition on hydrology of Western South Dakota ranges. South Dakota State Agr. Exp. Sta., Bull. 647, Brookings, S.D. pg 54.

Flanagan, D.C. and S.J. Livingston. 1995. WEPP user summary. NSREL Rep. 11, National Soil Erosion Lab. West Layette, Ind. 300 Pgs.

Frasier, G.W., R.H. Hart, and G.E. Schuman. 1995. Rainfall simulation to evaluate infiltration/runoff characteristics of a shortgrass prairie. J. Soil \& Water Cons. Soc. 50:460-465.

Frasier, G.W., M. Weltz, and L. Weltz. 1998a. Technical note: rainfall simulation runoff hydrograph analysis. J. Range Manage. 51(5):531-535.

Frasier, G.W., M.J. Trlica, Wayne C. Leininger, Robert A. Pearce, and Alexander Fernald. 1998b. Runoff from simulated rainfall in 2 montane riparian communities J. Range Manage. 51:315-322.

National Research Council Committee on Rangeland Classification (NRC). 1994. Rangeland health: new methods to classify, inventory, and monitor rangelands. Board of Agr., Nat. Res. Council, Nat. Acad. Press, Washington, D.C.

Packer, P.E. 1951. An approach to watershed protection criteria. J. Forest. 49:639-644.

SAS 1988. SAS/STAT User's Guide. SAS Institute Inc. Cary, N.C. 1028 p.

Simanton, J.R., M.A. Weltz, and H.D. Larsen. 1991. Rangeland experiments to parameterize the water erosion prediction project model: vegetation canopy cover effects. J. Range Manage. 44(3):276-282.

Spaeth, K.E., F.B. Pierson, M.A. Weltz and J.B. Awang 1996. Gradient analysis of infiltration and environmental variables as related to rangeland vegetation. Trans. ASAE 39:67-77.

Stone, J.J., L.J. Lane, and E.D. Shirley. 1992. Infiltration and runoff simulation on a plane. Trans. ASAE 35 (1):161-169.

Swanson, N. P. 1965. Rotating-boom rainfall simulator. Trans. ASAE 8:71-72.

Tiscareno-Lopez, M., V.L. Lopes, J.J. Stone, and L.J. Lane. 1993. Sensitivity analysis of the WEPP watershed model for rangeland application I: hillslope processes. Trans. ASAE 36 (6):1659-1672.

Thurow, T.L., W.H. Blackburn, and C.A. Taylor, Jr. 1986. Hydrologic characteristics of vegetation types as affected by livestock grazing systems, Edwards Plateau, Texas. J.
Range Manage. 39:505-509.

USDA-NRCS. 1997. National range and pasture handbook. United States Dept. Agr. Nat. Res. Cons. Serv.., Washington D.C.,

USDA-SCS 1976. National range handbook. United States Dept. Agr., Soil Cons. Serv. Washington D.C.

Weltz, L., 1995. Hydrologic responses of shortgrass plant communities. M.S. Thesis. Colorado State University, Fort Collins, Colo. 38 pgs.

Weltz, M.A. and M.K. Wood. 1986. Short duration grazing in central New Mexico: effects on infiltration rates. J. Range Manage. 39:365-368.

Weltz, M.A., A. B. Arslan, and L.J. Lane. 1992. Hydraulic roughness coefficient for native rangelands. J. Irrig. and Drain. Div. ASCE. 118(5):776-790.

Wood, M.K, 1987. Plot numbers required to determine infiltration rates and sediment production on rangelands in south central New Mexico. J. Range Manage. 40:259-263. 